DOI: $10.17516 / 1997-1370-0500$

УДК 378.095

\title{
Formation of Leading Universities: World Practice and Russian Perspective
}

\author{
Valerii S. Efimov and Alla V. Lapteva* \\ Siberian Federal University \\ Krasnoyarsk, Russian Federation
}

Received 26.08.2019, received in revised form 16.10.2019, accepted 18.12.2019

\begin{abstract}
The subject of the research presented is the phenomenon of university leadership and its conditions and factors.

The study is based on "success stories" of leading universities in various countries: Harvard and Stanford Universities (USA), Massachusetts Institute of Technology (USA), Shanghai Jiao Tong University (China), Indian Institute of Technology Bombay (India), Pohang University of Science and Technology (Korea), National Research University Higher School of Economics (Russia).

We can conclude that universities become leaders if they manage to "ride the wave" of important changes for society and support the deployment of these processes, as well as use their energy and the emerging opportunities. An important factor is the activity of key partners that support the development of a leading university: professional communities, authorities, governmental institutions and large companies.

The impact of leading universities on the development of the regions and countries where they are located is formulated as follows: they form elites; create an educated society, bring up professionals; produce and distribute new knowledge, technological, organizational and institutional solutions; directly develop the economy through the creation of new enterprises and jobs. Leading universities initiate cooperation on a regional and global scale; solving the problems faced by the humanity; they set new future-oriented objectives and goals.

In the history of universities, we can observe various relations with the state: partnership of universities and authorities or state domination over universities. The implementation of the strategic interests of the state can be combined with the freedom and activeness of universities, modelling the promising practices of the future "on themselves". At the same time, the situation in Russia is characterized by the actual absence of "universities as communities" demonstrating a high level of academic autonomy, their own vision of the prospects for the economy, technology, science, education and formulating their own independent strategies.
\end{abstract}

Keywords: universities, leadership, leadership factors, success stories, universities and the state.

\footnotetext{
(C) Siberian Federal University. All rights reserved

* Corresponding author E-mail address: Vefimov@sfu-kras.ru, alapteva@sfu-kras.ru ORCID: 0000-0002-6923-6543 (Efimov); 0000-0002-0252-8680 (Lapteva) 
The study was supported by the Russian Foundation for Basic Research and the Krasnoyarsk Regional Fund for Support of Research and Research and Technical Activities in the framework of the project "Regional Intellectual Ecosystem (R\&D, Education, Innovations) for the Krasnoyarsk Territory (Krai): a scientific and methodological analysis of new opportunities for education, research and innovation in the digital world frame; development of a system model of the "intellectual ecosystem" of the region; development of a digital platform as the basis of this ecosystem" No. 18-410-242007.

Research area: social philosophy.

Citation: Efimov, V.S., Lapteva, A.V. (2020). Formation of leading universities: world practice and Russian perspective. J. Sib. Fed. Univ. Humanit. Soc. Sci., 13(6), 860-875. DOI: 10.17516/1997-13700500 .

\section{Introduction}

Universities emerged in the European civilization as special cognitive institutions focused on technological, economic and social development issues.

The pursuance of leadership among states and regions is one of the key factors for the development of the humankind. The need for creation and reinforcement of competitive advantages forces the states, companies, and communities to invest into the development of knowledge, technologies, and institutional conditions for a wide range of innovative activities.

The leading universities make a powerful impact on the development of cities, regions, and countries of their presence, by means of: 1) forming a new elite generation; 2) "production" of professionals, bringing up an educated stratum of society; 3 ) development of various spheres of activity (economy, social sphere, politics, culture, personal life): creation and dissemination of new technologies, technical, organizational and institutional solutions; development of new ideas, values, and meanings; 4) immediate investment into economic development by creating new enterprises, generation and maintenance of jobs in the region.

It is of immediate interest today to study the university leadership phenomenon, to determine the conditions and factors facilitating the achievement of leadership. The history has witnessed multiple changes of leader universities: at first, the universities of Britain, then Germany were the models to emulate; later, this position was occupied by American universities.

It means that the emulation of the today's leaders does not guarantee an equally strong position in the future. Apart from that, the respectable universally acknowledged universities with many years' reputation are not the only ones the national innovative systems are in need of. The "forefront" of the science and technology development is associated with the technological and institutional innovations, the "boiling bed" where intensive interaction and synergy of the established and newly emerging technological solutions and institutional forms take place.

Until today, the leading universities have been satisfying the following criteria: scope of activity (number of students and professors, budget turnover); performance indicators (as a rule, quantitative indicators: number of publications in high-impact journals etc.); status and prestige (reputation in the academic community and business environment). Global and national ratings pull these properties together, and, therefore, the leaders are the highest rated universities. There is also a concept of "world class universities" (Salmi \& Frumin, 2007; Sal$\mathrm{mi}, 2009$ ) and the factors determining their development have been formulated.

There are some attempts of avoiding the established concept of a leader university. For instance, a collection of works edited by J.A. Douglass (Douglass, 2016) stipulating the concept of a "flagship university" is worth noticing. A flagship university is distinguished with 
the compound purposes: its activity is focused not only on the development of new knowledge and productive learning, but also on the progress of society (contributing to a more equitable and prosperous society) and advancement of individual human capabilities (Douglass, 2016). V. Efimov (2017a) suggests the "frontier university" concept: leadership means that the university acts as a subject and a "platform" for deployment of new trends in science, technology, social practice, expanding the horizon of humankind existence, creating new opportunities for cognition, production, social and personal life by "setting up the future".

A frontier university works to solve some special tasks: to remove the current thinking constraints (what and how can be thought of), to formulate new problems and challenges, to formulate new values and objectives, to develop new communities and collaborations.

The objective of the present paper is to study the success factors of the leader universities, including the established environment conditions and the efforts of the university management and community.

The university development cases described are cited from works of various authors (Altbach \& Salmi, 2011; Salmi, 2009; Wissema, 2009; Indiresan \& Nigam, 1993; Kuz'minov, 2002; 2006; Lester, 2017; Weintraub, 2014; Stratton \& Mannix, 2005 etc.) and materials accessible on the official websites of the universities.

\section{Leading University Value \\ for Countries and Regions}

\subsection{Development of the Society Elite}

Since the emergence of the first university in medieval Europe, universities have been in charge of "nurturing" the elite, educating those who, due to their aristocratic origin or belonging to a wealthy family, was to acquire influence and power, to become the carriers of culture, thought and action, certain world outlook, values and metal mindsets. Importantly, it is the common cultural and axiological platform, common experience and belonging to the student fraternity that created a certain level of unity and cohesion of the elite. As the democratic society was established, the elite became more meritocratic and open, and the universities began to play a role of social elevators, supplying the economic, political and cultural elite with talented people from various strata of society. The examples of flagship universities associated with the "elite breeding" are Oxford and Cambridge Universities in the United Kingdom and Harvard University in the USA.

Thus, among Oxford alumni there are 29 Nobel prize winners (in total, there are 69 Nobel prize winners connected to Oxford in any way, i.e. studied or lectured there), 27 prime ministers of the United Kingdom, 30 heads of other states (Complete..., 2019). In the list of famous Oxonians there are over 200 persons, from Roger Bacon and William of Ockham (13th-14th centuries) to William Golding, Tony Blair, Edwin Hubble (20th century) (Famous Oxonians, 2019). 275 thousand people of Oxford graduates live and work almost in all countries of the world (International profile, 2019).

The list of outstanding Cambridge alumni includes 11 monarchs and 21 members of royal families (of the United Kingdom, Iraq, Jordan, Bahrein, Japan), 15 prime ministers of the United Kingdom and 32 leaders (presidents, prime ministers) of 17 countries, dozens of political and religious figures, distinguished writers and poets, musicians, entrepreneurs, philanthropists etc. (List..., 2019).

\subsection{Forming the Educated Stratum of Society, Training Professionals}

An illustrative example is Paris University, where by the end of the 14th century studied up to 4000 students at a time, which is an enormous number for the Medieval Age (Dokumenty..., 1973). According to historical evidence, in the early 13 th century the number of Bologna University students was at least several hundred: only the German fraternity in the years 1289-1299 embraced 533 people, and in the first decades of the 14th century it was 1,259 people. It is impossible to imagine the development of European urban civilization of the late Medieval and the Modern Ages without universities that supplied cities with lawyers, theologians, diplomats, and later with scientists and engineers. 
At the present moment, the largest universities educate tens and hundreds of thousands of students at a time. Thus, at the City University of New York there are 124 thousand students (full time equivalent - FTE), at the University of Toronto - 74 thousand FTE (90 thousand in total), at Benemérita Universidad Autónoma de Puebla (Brazil) - 81 thousand FTE, at Istanbul University (Turkey) - 123 thousand FTE, at Universidad de Guadalajara (Mexico) - 127 thousand FTE (241 thousand in total), at AlImam Mohammad Ibn Saud Islamic University (Saudi Arabia) - 198 thousand FTE students (according to QS World University Rankings 2019). Having a university is a mandatory requirement for any large city or a regional centre.

\subsection{Immediate Contribution into \\ the Development of Regional and National Economy}

The outstanding examples of the universities that made significant contributions into the development of regional and national economies can be presented through the properties of Oxford and Cambridge Universities in the United Kingdom.

Oxford University is a catalyst of national and regional economy; its activity determines the position of Oxfordshire as one of the European flagship centres of innovation and entrepreneurship: the majority of the 1,500 high tech companies of the region are connected to Oxford. According to BiGGAR Economics (2017), in the years 2014/15 the contribution of the university into national economy constituted $£ 5.8$ billion of GVA (Gross Value Added); generally, the university maintains 50.6 thousand jobs in the country. The activity of the innovative companies of the university has yielded the revenue of $£ 320$ million and provided 5700 jobs. The University is the main place of touristic interest in Oxford City, attracting an enormous number of visitors with its museums, historical buildings, scientific and cultural events (43\% of touristic activity in Oxford City, 3450 jobs in the city, GVA of $£ 99$ million).

The staff of the innovative infrastructure of the University (Oxford Science Park and Begbroke Science Park) counts around 3 thousand people who create additional GVA of $£ 167$ million. In total, the number of people working in all the companies of the world established by the University is 4155 people; over 3,000 of them work in the United Kingdom, in 2014/15 creating a general turnover of almost $£ 600$ million all over the world and $£ 400$ million in the United Kingdom. Oxford has produced more "unicorns" (founders of companies with a current valuation of US\$1 billion or more) than any other European university (BiGGAR Economics, 2017).

Cambridge University is the centre of the European largest technological cluster that began to develop with the establishment of Cambridge Consultants in 1960 and the Cambridge Science Park in 1970. In the years 1960-1969, 39 new companies were established; in the 1970-s - 137, and by 1990 the rate of new company foundation reached the average value of two per week. Today, the cluster provides 57 thousand jobs in more than 1.5 thousand high tech companies with the aggregate annual revenue exceeding $£ 13$ billion. They formed an integrated infrastructural system including a research park, the university with its colleges, St.John's Innovation Centre, Peterhouse Technology Park, The Cambridge Judge Entrepreneurship Centre, IdeaSpace Enterprise Accelerator (The Cambridge Cluster, 2019). The University is a major employer, provider of technologies, source of knowledge and competence for the entire region. The entrepreneurship of Cambridge University is deployed through its affiliate Cambridge Enterprise, that facilitates commercialization of ideas and projects of its employees and students, encourages partnerships and business networking. Cambridge Enterprise supports over 60 innovative companies; since 1995, the companies included into its portfolio received the total financial subsidies of over $£ 1.29$ billion. At the moment, the staff of these companies exceeds 1 thousand people working in the spheres of healthcare, "green" energy, information and telecommunication technologies.

\section{Universities as Global and National Leaders: Success Factors}

This chapter presents the cases of the world flagship universities, indicating the special sit- 
uations of their success stories and identifying the success factors that brought the university to its leadership position. It involves the stories of the leading universities of the USA, China, India and South Korea, along with the relatively young National Research University Higher School of Economics (Russia).

\subsection{Harvard University, USA}

Harvard College was initially founded as a classical education institution, in the image and likeness of Cambridge University in the United Kingdom, a university producing political and financial elite. Throughout its history, Harvard has been playing the role of an "incubator" for the national American and global elite, determining its way of thinking and acting. Among Harvard graduates there is a great number of large business and financial leaders, intellectuals, representatives of the political establishment, such as 32 heads of different states of the world, including eight presidents of the USA. Among its alumni there are 62 of currently living billionaires (record for universities) (Harvard..., 2019).

Due to the accelerating industrialization, in the mid-19th century, the country was in need for more specialists in natural science and engineering. The teaching approaches of that time, focused on rote memorization and reproduction of texts could not satisfy that need; that caused a university crisis. The first ones to cry for changes were the representatives of business community, many of which were Harvard alumni.

In 1865 , the university management was reformed, and control over the university was transferred from the Council of State to the Board of Overseers consisting of the university graduates. It enabled the university to reform its activity, to get to the top of global ratings and to create a unique community of graduates (2018 Election..., 2019). Thus, Harvard University managed to "ride the wave of industrialization" and take the best of it.

In 1869, the president of Harvard University was the 35-year-old analytical chemistry professor Charles V. Elliot, who successfully reformed the methods and forms of education (Historical Facts, 2019). Rote memoriza- tion was replaced with lectures and seminars where knowledge was brought into practice. To ensure better connection to practice, the case study method was introduced to make students analyse some real or "modelled" situations using the newly acquired theoretical knowledge. New education approaches were based on the actual requests of the professional communities (legal etc.) for the development of critical thinking, proving and discussing skills (Garvin, 2003). Elliot was the one to substantiate the need for a "Tax Deductions for Charitable Donations" widely spread in the USA. Due to this practice, Harvard University got the opportunity to expand its endowment, developing into a billionaire university.

In the second half of the 20th century international leadership of the USA and involvement of larger number of countries into the globalisation process brought Harvard to the position of a leader university forming the global political, financial, industrial and intellectual elites.

The new challenge, determined by the digital revolution achievements, faced by Harvard in the early 21 st century, is now being overcome in cooperation with the newwave flagship universities: Massachusetts Institute of Technology and others (HarvardX, 2019).

\section{Harvard University Success Factors}

- Systematic work with graduates, establishment of the brand and community of Harvard alumni, involvement of graduates into the university activity facilitated the development of the global Harvard alumni community and creation of the largest university endowment fund.

- Establishment of a special university management model: its policy is determined not by the state officials, but by a professional community, the Board of Overseers, that ensures a tight bond between the university and the processes taking place in the place.

- Economic model of managing the endowment as an investment fund by financial investment specialists.

- Development of education approaches, branches and programs based on the current requests of the professional communities. 
- Creation of new opportunities for selection of individual curricula for students and post-graduates with a system of elective subjects.

- Involvement of best students and professors from different countries. Harvard University facilitated the globalization processes and took the advantages of their effects to cooperate with the foreign stakeholders and to promote itself as the best elite university.

\subsection{Stanford University /}

\section{Leland Stanford Junior University, USA}

In the first decades of its existence, Stanford was a regional university, not outstanding in scale or financial capacity. The earthquake in 1906 that destroyed a part of its campus aggravated the financial problems.

In 1920-s, one of its first graduates, Herbert Hoover, who later became the 31st President of the USA, played a critical role in the university development. Hoover was a member of the Board, lectured at Stanford, founded the future Hoover Institution (public policy study centre) and the School of Business. Nevertheless, until the mid-20th century Stanford remained a regional university unable to compete with the flagship universities for bright students or alumni. The economic situation of the university was determined with its low budget and large areas of empty agricultural lands.

The first step to changing the situation was made at the end of the 1930-s, when the Dean of the Stanford School of Engineering Frederick Terman came up with the idea of involving the university graduates into the life of alma mater: they were offered a long-term lease of land for high tech companies under advantageous conditions including tax preferences (Timeline..., 2019). In 1946, Stanford Research Institution was opened to provide employment to the talented students and alumni of California universities. In 1958, the Small Business Investment Act (The Small Business...) was enacted at the federal level to allow the Small Business Association to register small investment companies with participation of the state capital. The law underlay the expansion of venture funds, minimizing the risks of investment into small high tech start-ups with tax preferences. The Consti- tution of California enacted a clause according to which any property of Stanford University used for education purposes was exempt from taxes (Grodin et al., 1993).

It resulted in the development of a region with the highest "density" of high tech companies, known as the Silicon Valley. The University acted as an "institutional innovator", the first to create the grounds for the university alumni to start their own companies and bringing the process to the avalanche scale. Among the conditions offered there was an option of accommodating a start-up at the industrial park of the University, start-up financing, consulting, "dense" entrepreneurship environment, high concentration of human resources, a special atmosphere of creativity, cooperation and entrepreneurship in the university and its surroundings. At the present moment, a great role is played by the special programs of the University and future entrepreneur training centres (Centre for Entrepreneurial Studies (CES), Stanford Venture Studio, Stanford Technology Ventures Program and others): over 35-50\% of innovators and company founders from the university graduates have participated in these programs.

Stanford is a pioneer among the universities contributing into economic development through the new companies started by its alumni. The aggregate annual revenue of these companies is estimated at US\$2.7 trillion, which is comparable to the volume of economy of a country rated as the tenth largest economy of the world (Study shows..., 2012). Since 1930, they have created 5.4 million jobs. With regard to California, the university alumni have created 18,000 companies with the annual production volume reaching US\$1.27 trillion and the number of employees exceeding 3 million people.

Moreover, Stanford is a "migration pump" of the region, accumulating the most valuable human resources from all over the world: talented and active young people, enthusiastic about creating new technologies and putting them into practice in new businesses. Thus, within the period from 1984 till 2010, from 44 to $56 \%$ of Stanford master's and post-graduate students came from abroad, and many of them 
got absorbed into the California entrepreneur community after graduation.

\section{Stanford University success factors}

- Development strategy including integration with high tech businesses, providing conditions for innovation development, structuring the education environment in cooperation with businesses.

- Selection of students and professors not only based on their academic capacities and achievements, but also on their belonging to the culture of entrepreneurship.

- Efficient economic management, using the territory for attraction of value creating companies.

Focus of the academic and scientific activities on the practical projects, networking, interdisciplinary research and bringing the students' projects to the market during their university studies.

Stanford University has been rated among the global leaders of the computer (information) revolution as a centre of deployment of the technological revolution. It managed to develop a region with a high density of innovative companies: an ecosystem with the inhabitants competing and cooperating with each other, reaching a higher level of activity and achievement. Importantly, the university changes its own priorities with regard to the changing technological development agenda and the shift of the "technological frontier". At the moment, the laboratories and research institutions of Stanford work in the areas associated with the sixth technology revolution: nanotechnologies and new materials, biotechnologies (genome, cell technologies etc.), neuroscience and artificial intelligence. A part of the research institutions is focused on the globally relevant social and cultural problems, such as demographic processes, problems of poverty and discrimination, political communication, urbanization etc.

\subsection{Massachusetts Institute}

\section{of Technology (MIT), USA}

MIT also refers to universities whose path to leadership has not been short and simple. Until the second decade of the 20th century, the Institute experienced significant financial diffi- culties, did not stand out among other technical educational institutions, and was in quite fierce competition with the better recognized Harvard University. In the period 1916-1930 significant transformations occured: moving and expanding the campus; raising corporate funds for applied research and training engineers; attracting donations from individuals. By the beginning of World War II, MIT became one of the leading centres of science and technology in the United States and the largest recipient of research and development funding from the defense and military industries (Stratton \& Mannix, 2005).

The Cold War brought the next wave of research and development funding. The Laboratory of Nuclear Science was opened in 1946, and the Lincoln Lab in 1951 (History, 2019). MIT, along with Stanford, received the official status of a leading research and development centre, operating in close conjunction with the military-industrial complex.

At the end of 1996, a committee was organized to prepare a new university development strategy. The report, prepared by Task Force on Learning and Student Life (1998) served as the starting point for the second wave of significant change. The university mission was updated, the principles of its activity were outlined, including the priority of knowledge that contributes to the society, and the value of fundamental knowledge, responsibility to society, learning through activities, combining liberal and professional education, orientation toward preparing for life, efficiency in achieving clearly defined goals, unity of the teaching community, the combination of teaching and research with social activities, interest and activity, the importance of diversity. Thanks to the turn of MIT towards liberalization and openness of education, it was possible to achieve leadership among the world's best entrepreneurial and innovative universities.

Currently MIT is one of the leading universities that are associated with technological entrepreneurship. Its graduates have established 30 thousand companies around the world, which is more than 4.5 million jobs. It is a partner of more than 700 companies, ensuring their competitiveness. Together with Har- 
vard and the research infrastructure of Boston, MIT forms the technological and scientific hub of the US East Coast. Today's tasks of the university are connected with the formation of a new sixth technological structure, the deployment of the digital revolution, artificial intelligence technologies and mass online education.

\section{MIT success factors}

- The leading role of the university since the middle of the 20th century in research and development for the needs of the US military-industrial complex.

- Skillful use of the proximity of an older university - Harvard, which has turned from a competitor into a partner; as a result, a single scientific and educational hub of the East Coast of the United States was formed.

- Compliance with the most advanced social, educational and research principles through regular updating and revision of internal standards regulating the activities of the university.

- Effective and flexible management based on the work of commissions engaged in the study and analysis of various areas of the university and the community of students and professors.

- Management aimed at global leadership: the university gains significant advantages and funds by working with the local community (state, city), the state, corporations and foreign partners.

MIT became one of the leading universities on the back of the deployment of the US military-industrial complex before and during World War II and in the subsequent period of military-technological competition of leading states. Then MIT continued confirming and strengthening its leadership in the epoch of digital revolution and formation of the new sixth technological mode. The university was one of the first to begin active research and development in the field of artificial intelligence and mass online education and moved from the category of national leaders to the category of global leaders.

\subsection{Shanghai Jiao Tong University, China}

Shanghai Jiao Tong University is one of the first universities in China (founded in 1896), and for decades it has been developing its own intellectual and reputation capital. Already in the 1930s, it gained fame as the best university for the training of engineers and researchers and got the name of the "Oriental Massachusetts Institute of Technology".

The high dynamics of the university development during the last two decades is due to the efforts of the state aimed at developing the tertiary education system to the international level. State policy towards the university includes a high degree of autonomy given to the institution and, at the same time, large-scale financial support. On the other hand, the efforts of SJTU itself have contributed to its advancement due to the transition from administrative to strategic management. Management activities include mid- and long-term assessment of the activities of faculties and departments, diversification of financial resources and innovation in personnel policy. The university takes into account the external environment in which it operates, as well as its organisational capabilities, global goals and its development vector. SJTU has shifted its focus from domestic to international standards, from the struggle for the domestic market to the formation of international competitiveness, from infrastructure development to improving the level of teaching, learning and research (Altbach \& Salmi, 2011).

In 1996, the year of the centenary, a "three-step plan" was developed for transforming SJTU by the middle of the 21 st century into a world-class research university. Departments are also required to create development programmes. 2004 was declared the "Year of Strategic Planning" during which the university development strategy until 2010 was developed (Altbach \& Salmi, 2011).

\section{SJTU success factors}

- the university is located in a rapidly developing country which aspires to the world economic and political leadership; it is located in a large city - the second largest in China and in the world; this position provides a high demand for graduates, for research and technological development;

- the key stakeholders of the university (founders) are the Ministry of Education and the Ministry of Emergency Management of the 
People's Republic of China, the Shanghai Municipal Government;

- the university is participating in the Project 211 funded by the Government aimed at creating world-class universities, and has received the necessary political and financial support;

- the university actively participated in the formation of the country's national elite: its graduates include Jiang Zemin, the general secretary of the Central Committee of the Communist Party of China in 1989-2002 and Chairman of the PRC in 1993-2003; more than 200 members of the Chinese Academy of Sciences and the Chinese Academy of Engineering;

- the university was able to move from the traditional administration to modern strategic management, which ensured the rapid growth of the university performance in world rankings.

SJTU became a leading university in the period of the dynamic growth of Chinese economy and its transformation into one of the leading economic powers in the world. This period included the "catching up" modernisation/ industrialisation of the Chinese economy, the achievement of significant openness and involvement in globalisation processes with the further transition of the avant-garde part of the country - its megacities - to the trajectory of post-industrial and innovative development. An important actor in China's economic breakthrough and SJTU's leadership position was the Chinese state, whose policy in both cases was highly effective.

\subsection{Indian Institute}

\section{of Technology Bombay (IITB), India}

After gaining independence in 1947 and for successful existence and competition with other countries, India needed to create modern industry and technology - the country needed a large number of engineers and technicians. In 1946, the Technical Education Development Committee recommended the establishment of four technical institutes in accordance with the model similar to Massachusetts Institute of Technology and not an English educational institution, such as King's College London
(Indiresan \& Nigam, 1993). The recommendations of the Committee were supported by the first Prime Minister of independent India, the pandit Jawarharlal Nehru and the first IIT was founded in May 1950 in Kharagpur, near Calcutta. Later, three more institutes were created: in Bombay (later renamed Mumbai) in 1958; in Madras (Chennai) in 1959; in Kanpur in 1959 (Altbach \& Salmi, 2011).

In 1961, according to the law adopted by the Parliament, the Institute was recognised as an institute of national importance and received the status of a university with the authority to award its own degrees and diplomas.

\section{IITB success factors}

- the university is located in a rapidly developing country, which aspires to the world economic and political leadership; it is located in the largest city of Mumbai with a population of 22.8 million (2015), with a high standard of living and business activity; this position provides a high demand for graduates, for research and technological development;

- the university was established and continues to operate within the framework of the government programme on the creation of Indian institutes of technology of national importance - these institutions fulfill the national task of supporting technological development processes through research and technological development and the training of modern scientific and engineering personnel;

- the university actively participated in the formation of the country's engineering and technological elite - many talented and world-famous developers and leaders of the modern economy are IITB graduates;

- the university has an efficient management system contributing to the rapid growth and high positions of the university in the world rankings.

IIT Bombay has become a national leading university and occupied a strong position in the world rankings as it was included in two consecutive periods of catching up with the economic and technological development of India. The first took place after the country gained independence. The second started with liberal economic reforms in 1991 and led to an acceleration of GDP growth to 5.5\% per year 
on average - the country entered the group of the fastest growing countries in the world. A significant factor in the formation and development of the university was the Indian state, for which the activities of the IITs system was an important tool for modernising the country.

\subsection{Pohang University of Science and Technology (POSTECH), the Republic of Korea}

POSTECH is one of the youngest universities in Korea - it was founded in 1986 by POSCO (Pohang Iron and Steel Company), one of the largest metallurgical companies in the world. It was founded in 1968 by the decision of the President of South Korea as part of the task of creating a full steel production cycle in the country as a key factor in the development of the economy and ensuring its self-sufficiency (History of POSCO, 2019). POSCO received financial and technological support from companies and banks in Japan. At the same time, POSCO managed to succeed in the market and began to compete with Japanese companies, as a result of which Japan stopped further transfer of technology to Korea. Understanding the need to ensure its own technological development, POSCO organised the Research Institute of Industrial Science and Technology in 1986 later POSTECH in order to provide modern education to promising engineers and lay the foundation for the development of future technologies.

Thus, the establishement of POSTECH was a response to the economic and technological challenges that South Korea faced, solving the strategic task of creating a modern competitive economy. The key factor in the success of POSTECH University is its involvement in solving the problems of technological development and staffing of its founder, POSCO company, which is one of the leading world metallurgical companies.

Significant financial support from POSCO and use of creative management strategies to attract talented scientists and students became important for POSTECH leadership (Altbach $\&$ Salmi, 2011). The university endowment consisting primarily of POSCO shares, has now reached approximately $\$ 2$ billion. POS-
TECH's financial well-being allows students not to be charged for tuition. They live on campus surrounded by stately buildings and study in state-of-the-art classrooms and laboratories (Altbach \& Salmi, 2011), which is also a strong competitive advantage of the university.

\section{POSTECH success factors}

- POSTECH was created and took a leading position during the period of rapid industrial development in Korea, the creation of a modern competitive economy in the country, when an urgent need arose to solve the problems of technological development and staff training for the industry.

- The key actor in the creation and development of the university was the Pohang Iron and Steel Company (POSCO), which the university was vitally important for in order to achieve and maintain competitiveness, a strong position among the world leading metallurgical companies. At the same time, POSTECH was not limited to the role of "providing" in relation to its key partner; this work served as a launching pad for the formation of the university. In the future, the university launched basic research and engineering in a wide range of areas, and currently seeks to become a globally significant centre for research and development in various fields of science and technology; it has been developing a network of partnerships with industrial companies and leading world universities.

\subsection{Higher School of Economics \\ National Research University (HSE), Russia}

The Higher School of Economics is a young and rapidly developing university established on November 27, 1992 by the Decree of the Government of Russia (Postanovlenie..., 1992). According to its rector Ya.I. Kuzminov, "they wanted to create a school in Russia that would teach modern economics, modern social theory at the level of world standards and world science" (Benediktov, 2010). Scientists-economists and political leaders interested in economic and democratic transformations in post-Soviet Russia participated in the creation and activities of the school. In 2008, the Higher School of Economics came to the jurisdiction of the Government of the Russian Federation, 
and the university was officially entrusted with expert and analytical support for the government's activities on issues of economic and social policy, state and municipal administration (Rasporiazhenie..., 2008).

The strategic goal of the Higher School of Economics is university-based development of an advanced scientific, educational, analytical, consulting and design centre in the field of social and economic sciences, one of the leading world research universities in the quality of its competencies and developments and a significant practical contribution to innovative development and Russia's global competitiveness.

\section{HSE success factors}

- The university was created during the period of deep political, economic and social transformation associated with the collapse of the Soviet Union and the formation of a new state, the Russian Federation. The idea of creating a new modern university belonged to a group of liberal economists (E.G. Yasin, Ya.I. Kuzminov and others) close to government circles of that time.

- During this period, the transfer of new economic, political, informational and humanitarian models and technologies and modern practices of socio-economic modernisation were important for the country. During this period of socio-economic transformations, the Higher School of Economics occupied the position of a leading centre for higher education, an analytical centre and a "think tank" that provides intellectual support for government reforms - research, development of strategies and policies, and training of new personnel. The key actor in the formation and development of the Higher School of Economics, its customer and partner is the government of the Russian Federation.

\section{Conclusions. Universities}

\section{on their way to leadership}

University leadership is always the result of a combination of external conditions and own efforts undertaken by the university community and key stakeholders for its development. Success factors of the university are closely related to the characteristics of the socio-political system of the country in which it operates. It is important to note that both in the liberal democratic countries and in the countries with an authoritarian system of government, the university community and the state play a key role in the development of the university. In some cases, a large company or a consortium of business companies can play such a role.

It should be emphasised that universities became leaders if they managed to "ride the wave" of changes important for the society to understand their nature and organise their activities in such a way that, on the one hand, they support the development of these processes, on the other hand, they use their energy and emerging resource flows.

Thus, Harvard University took the lead in the wake of the formation of the first national American, and then global political, industrial, financial elites. The ascent of Stanford University is associated with the computer revolution, and today it retains leadership positioning itself as the leading centre of the sixth technological order and claiming to solve the problems that the humanity faces (in the field of medicine, energy, environmental conservation, etc.). Massachusetts Institute of Technology has taken a strong position, first providing (through scientific and technological developments) the formation of the US military-industrial complex, and later joining the digital revolution, forming the foundations of the sixth technological order. Shanghai Jiao-Tong University used the energy of modernisation and industrialisation of China and is currently actively involved in the post-industrial and innovative development of the country's leading economic centres. Indian Institute of Technology of Bombay has become a leading university, being included in two successive periods of economic and technological development of India: the first unfolded after independence, and the second after liberal economic reforms in 1991. Pohang University of Science and Technology in Korea took the lead during the period of rapid industrial development in Korea, the creation of a modern competitive economy, which required the solution of problems of technological development and training specialists for industry, first of all. National Re- 
search University Higher School of Economics in Russia was created and achieved leadership in the wake of market reforms in the Russian economy and institutional modernisation of Russian society and the state. The University has taken up the position of a higher education centre producing new personnel, an analytical centre and a "think tank" that provides intellectual support for reforms.

Each example allows to single out certain "forces", key partners who needed the university's activities and supported its development as a leader. If we talk about Harvard and Stanford universities, these are primarily professional communities. In case with Massachusetts Institute of Technology it was the state, federal agencies (NASA, etc.). For the universities of China and India (Shanghai Jiao-Tong University, Indian Institute of Technology Bombay), the state was a key partner as well. For Pohang University of Science and Technology in Korea, such a partner was the largest Korean industrial company, Pohang Iron and Steel Company (POSCO), one of the leading metallurgical companies in the world. The key partner that had a decisive influence on the processes of formation and development of Higher School of Economics in Russia was the Russian government.

The analysis of the success stories of these leading universities allows to make a number of conlcusions.

1. It is important to understand that there is leadership in the modern world in relation to universities, countries and regions, and that there are certain ways to gain and maintain it. The model of leadership as domination is becoming a thing of the past. A different type of leadership becomes more relevant: leading countries are the first to create new technologies, develop new forms of economic, social and political organisation, and initiate cooperation on a regional and global scale. They declare their readiness to solve the most urgent problems and respond to the challenges that the humanity faces as a whole: a lack of various resources; maintaining health and improving the quality of life of people; development of new spaces for human activities - space, the ocean, the microworld, etc. Leaders create new mean- ings, set new goals, thereby setting the possibilities and energy of moving into the future.

Leading universities are in the centre of creating new opportunities: they shift the limits, create new paradigms of thinking, new technologies and new activities. Universities turn into key cognitive institutions which: a) accummulate requests of economy and society for new knowledge and technology; b) outline problems and tasks for research and development; c) play the role of intellectual centres creating network cooperations of researchers; d) implement advanced, breakthrough research and developments; e) develop new technologies and products that penetrate the economy with high speed through the intellectual property turnover mechanisms or the launch of new businesses.

2. The world's leading universities have a significant impact on the development of the cities, regions and countries to which they belong as they: a) form political, economic, intellectual and cultural elites; b) create an educated society, train professionals; c) produce and disseminate new knowledge, technologies, technical, organizational, institutional solutions for various fields - economics, social sphere, politics, culture, personal life; d) directly develop the economy through the creation of new enterprises and jobs in the region.

3. It is necessary to understand that the university as an institution of society changes radically in the course of history. The differences between the universities of the Middle Ages, the industrial era and the post-industrial world are so great that we can talk about different generations of universities - just like we talk about different generations of technology working on the basis of different physical principles. The task of forming the leading universities should take into account the generational change and the differences between them.

Currently, we can talk about the formation of the fourth generation of universities: a generation that is associated with the formation of "cognitive society" and that will become the leading subject of this process (Efimov \& Lapteva, 2017b). University 4.0 should become a search and experimental platform where new 
configurations of thinking and activity, new social and anthropological practices are modeled and tested.

4. In the history of universities, various types of the relationship between the university and the state can be traced. The two most common options are partnership relations between universities and the state and relations of state domination over universities. In the first case, universities have a high level of autonomy and independence; in the second, they are more similar to a tool which the state uses to solve its tasks. A special type of relations is also possible, which combines the realization of the strategic interests of the state with the wide freedom and high activity of universities engaged in research and design activities modelling promising future practices on their own example.

Owing to the peculiarities of its history, Russia actually lacks "universities of societies", i.e. highly autonomous universities that independently build their strategies with the participation of professional or regional communities, have their own vision of the prospects for the economy, technology, science, education and determine their strategic goals on the basis of this vision. Public policy gravitates to the model of state dominance in relations with universities.

\section{References}

2018 Election Results: Harvard Overseers and HAA Elected Directors (2019). Available at: https:// www.harvard.edu/elections-2018 (accessed 21 June 2019).

Altbach, P. \& Salmi, J. (eds) (2011). The Road to Academic Excellence: The Making of World-Class Research Universities. Washington, DC, The World Bank, 363 p.

Benediktov, K. (2010). GU VSHE: istoriia uspeshnogo eksperimenta [HSE: the story of a successful experiment]. Available at: https:/www.hse.ru/news/1163603/26596922.html (accessed 21 June 2019).

BiGGAR Economics (2017). Economic Impact of the University of Oxford: A report to University of Oxford. Available at: https://www.ox.ac.uk/sites/files/oxford/Economic\%20Impact\%20of\%20the\%20University\%20of\%200xford.pdf (accessed 21 June 2019).

Complete University Guide. University of Oxford (2019). Available at: https://www.thecompleteuniversityguide.co.uk/oxford/ (accessed 21 June 2019).

Dokumenty po istorii universitetov Evropy XII-XVvv. (1973). [Documents on the history of European universities in the $12^{\text {th }}-15^{\text {th }}$ centuries]. Voronezh, Voronezh State Pedagogical Institute, $157 \mathrm{p}$.

Douglass, J.A. (ed.) (2016). The New Flagship University: Changing the Paradigm from Global Ranking to National Relevancy. Basingstoke - N. Y., Palgrave Macmillan, 217 p.

Efimov, V.S. \& Lapteva, A.V. (2017a). Universitet frontira: na puti k novomu pokoleniiu institutov razvitiia [Frontier university: on the way to new generation development institutions], In Universitetskoe upravlenie: praktika i analiz [University Management: Practice and Analysis], 6(21), 6-18. DOI: 10.15826/ umpa.2017.06.070

Efimov, V.S. \& Lapteva, A.V. (2017b). Universitet 4.0: filosofsko-metodologicheskii analiz [University 4.0: Philosophical and Methodological Analysis], In Universitetskoe upravlenie: praktika i analiz [University Management: Practice and Analysis], 1, 16-29.

Famous Oxonians (2019). Available at: http://www.ox.ac.uk/about/oxford-people/famous-oxonians (accessed 21 June 2019).

Garvin, D.A. (2003) Making the Case: Professional Education for the World of Practice, In Harvard Magazine, September-October 2003, 56-65. Available at: https://harvardmagazine.com/2003/09/makingthe-case-html. (accessed 21 June 2019).

Grodin, J.R., Massey, C.R. \& Cunningham, R.B. (1993). The California State Constitution: A Reference Guide. Westport, Connecticut, Greenwood Press, 311 p.

Harvard at a Glance (2019). Available at: https://www.harvard.edu/about-harvard/harvard-glance (accessed 21 June 2019). 
HarvardX: About Us (2019). Available at: https://harvardx.harvard.edu/who-we-are (accessed 21 June 2019).

Historical Facts (2019). Available at: https://www.harvard.edu/about-harvard/harvard-glance/history/ historical-facts (accessed 21 June 2019).

History (2019). Available at: https://www.ll.mit.edu/about/history (accessed 21 June 2019).

History of POSCO (2019). Available at: http://www.posco.com/homepage/docs/eng6/jsp/company/ posco/s91a1000012c.jsp (accessed 21 June 2019).

Indiresan, P.V. \& Nigam, N.C. (1993). The Indian Institutes of Technology: Excellence in Peril, In Higher Education Reform in India: Experience and Perspectives, ed. Suma Chitnis and Philip G. Altbach, New Delhi, Sage Publications India, 334-363.

International profile (2019). Available at: https://www.ox.ac.uk/about/international-oxford/oxfords-international-profile?wssl=1 (accessed 21 June 2019).

Kuz'minov, Ia.I. (2002). Tsentry mozgovykh atak? Atakuite! [Brainstorming centers? Attack!]. Available at: http://www.soob.ru/n/2002/10/op/0 (accessed 21 June 2019).

Kuz'minov, Ia.I. (2006). Vysshaya shkola ekonomiki: missiya i mekhanizmy ee realizatsii [Higher School of Economics: mission and mechanisms for its implementation], In Universitetskie innovatsii: opyt Vysshei shkoly ekonomiki [University Innovations: Higher School of Economics Experience], Moscow, Higher School of Economics Publ., 7-12.

Lester, R.K. (2017). A Global Strategy for MIT. Cambridge, MA, 44 p. Available at: https://facultygovernance.mit.edu/sites/default/files/reports/2017-05_A_Global_Strategy_For_MIT_0.pdf (accessed 21 June 2019).

List of University of Cambridge people (2019). Available at: https://en.wikipedia.org/wiki/List_of_ University_of_Cambridge_people (accessed 21 June 2019).

Postanovlenie Pravitel'stva Rossiiskoi Federatsii ot 27 noiaabria 1992 g. No. 917 "O sozdanii Vysshei shkoly ekonomiki" [Resolution of the Government of the Russian Federation of November 27, $1992 \mathrm{~N} 917$ "On the creation of the Higher School of Economics"]. Available at: http://base.garant.ru/6310008/ (accessed 21 June 2019).

QS World University Rankings (2019). Available at: https://www.topuniversities.com/universities (accessed 21 June 2019).

Rasporiazhenie Pravitel'stva RF ot 12 avgusta 2008 g. No. 1177-p [Order of the Government of the Russian Federation of August 12, 2008 No. 1177-p]. Available at: http://www.garant.ru/products/ipo/prime/ doc/6291162/ (accessed 21 June 2019).

Salmi, J. \& Frumin, I.D. (2007). Rossiiskie vuzy v konkurentsii universitetov mirovogo klassa [Russian colleges in the competition of leading world universities], In Voprosy obrazovaniya [Educational Studies Moscow], 3, 5-45.

Salmi, J. (2009). The challenge of establishing world-class universities. Washington, DC, The World Bank, $115 \mathrm{p}$.

Stratton, J.A. \& Mannix, L.H. (2005). Mind and Hand: The Birth of MIT, Cambridge, MA, MIT Press, $792 \mathrm{p}$.

Study shows Stanford alumni create nearly \$3 trillion in economic impact each year (2012). Available at: https://news.stanford.edu/news/2012/october/innovation-economic-impact-102412.html (accessed 21 June 2019).

Task Force on Learning and Student Life (1998). Available at: http://web.mit.edu/committees/sll/tf.ht$\mathrm{ml}$ (accessed 21 June 2019).

The Cambridge cluster (2019). Available at: https://www.cam.ac.uk/research/innovation-at-cambridge/the-cambridge-cluster (accessed 21 June 2019).

The Small Business Investment Act of 1958. Available at: https://www.sba.gov/sites/default/files/ Small\%20Business\%20Investment\%20Act\%20of\%201958_0.pdf (accessed 21 June 2019).

Timeline of our history (2019). Available at: http://www8.hp.com/us/en/hp-information/about-hp/history/hp-timeline/timeline.html (accessed 21 June 2019). 
Weintraub, E.R. (2014). Telling the story of MIT Economics in the Postwar Period, In History of Political Economy, 46 (annual suppl.), Duke University Press, 1-12. DOI: 10.1215/00182702-2716091

Wissema, J.G. (2009). Towards the Third Generation University: Managing the University in Transition. Cheltenham, Edward Elgar Publishing, 272 p.

\title{
Становление университетов-лидеров: мировая практика и российская перспектива
}

\author{
B.C. Ефимов, A.B. Лаптева \\ Сибирский федеральный университет \\ Российская Федерация, Красноярск
}

\begin{abstract}
Аннотация. Предметом исследования является феномен лидерства университетов, условия и факторы, способствующие его достижению. В качестве материала использованы «истории успеха» ведущих университетов различных стран: Гарвардского и Стэнфордского университетов (США), Массачусетского технологического института (США), Шанхайского университета Цзяо-Тун (Китай), Индийского института технологий Бомбея (Индия), Пхоханского университета науки и технологий (Корея), Национального исследовательского университета «Высшая школа экономики» (Россия). Показано, что университеты становились лидерами, если им удавалось «поймать волну» важных для общества изменений и, с одной стороны, поддерживать развертывание этих процессов, с другой - использовать их энергетику и возникающие возможности. Также можно выделить ключевых партнеров, которые поддерживали становление университеталидера, - профессиональные сообщества, государство и правительственные агентства, крупные компании. Обсуждается воздействие ведущих университетов на развитие регионов и стран, к которым они принадлежат: они формируют элиты; создают образованное общество, выращивают профессионалов; производят и распространяют новые знания, технологические, организационные, институциональные решения; непосредственно развивают экономику через создание новых предприятий и рабочих мест. Университеты-лидеры инициируют сотрудничество в региональном и глобальном масштабе, решение стоящих перед человечеством проблем, задают новые смыслы и цели - энергетику движения в будущее. В истории университетов прослеживаются различные варианты их взаимоотношений с государством: партнерство университетов и государственной власти либо доминирование государства над университетами. Возможно также сочетание реализации стратегических интересов государства с широкой свободой и высокой активностью университетов, моделирующих «на себе» перспективные практики будущего. Особенность ситуации России состоит в фактическом отсутствии «университетов-сообществ», обладающих высоким уровнем академической автономии, имеющих собственное видение перспектив экономики, технологий, науки, образования и формулирующих свои стратегии.
\end{abstract}

Ключевые слова: университеты, лидерство, факторы лидерства, истории успеха, университеты и государство. 
Исследование выполнено при финансовой поддержке Российского фонда фундаментальных исследований и КГАУ «Красноярский краевой фонд поддержки научной и научно-технической деятельности» - проект «Региональная «интеллектуальная экосистема» (R\&D, образование, инновации) Красноярского края: научно-методологический анализ новых возможностей исследовательской, образовательной, инновационной деятельности в условиях цифрового мира; разработка системной модели «интеллектуальной экосистемы» региона; создание действующей цифровой платформы как основы данной экосистемы» № 18-410-242007.

Научная специальность: 09.00.11 - социальная философия. 